\title{
Comparing Data Collection Methods in Phenological Evaluations of Himatanthus drasticus
}

Marília Grazielly Mendes dos Santos ${ }^{1}$

Lia d'Afonsêca Pedreira de Miranda ${ }^{2}$

Ligia Silveira Funch ${ }^{3}$ (])

\begin{abstract}
We present a case study focusing on collection methods and phenological data analyses. Qualitative, semi-quantitative, and quantitative approaches were compared in terms of their efficiencies for describing flowering and fruiting intensities and phenophase synchrony in Himatanthus drasticus growing in a gallery forest in the Chapada Diamantina mountains, Brazil. Our results showed that phenophase intensity and synchrony were respectively each best. Determined using quantitative and qualitative methods We reinforce the importance of clearly defining research aims, as quantitative data collections require considerably greater field efforts than qualitative evaluations, especially concerning forest trees.
\end{abstract}

Keywords: intensity, reproductive phenology, synchrony.

Phenophase synchrony and intensity are criteria of fundamental importance for examining the seasonal timing of plant life history events. Phenological synchrony is considered the simultaneous occurrence of the same type of event among distinct individuals (or species); the intensity, or amplitude, of a life-phase phenomenon considers the quantification of that phenological activity, which can be measured considering individuals, populations, species, or communities (Newstrom et al., 1994). A wide variety of methods for data collection, evaluation, and analysis have been employed to examine the synchrony and intensity of plant phenological events using qualitative, semi-quantitative, and quantitative methods (Bencke \& Morellato, 2002; Morellato et al., 2010a, Alexander \& Woeste, 2016). Semi-quantitative approaches establish predefined scales without the use of exact measurements (Fournier, 1974; Pugas et al., 2018; Araujo \& Lobo 2020) or percentages of canopy cover (Lenza \& Klink, 2006). Intensity analyses, on the other hand, are measured or estimated (Bencke \& Morellato, 2002; CastroDíez et al., 2003), and most evaluations of synchrony have been based on qualitative data (Augspurger, 1983; Bolmgren, 1998; Bencke \& Morellato, 2002; Morellato et al., 2010b; Baldauf et al., 2014; Rodriguez-Pérez \& Traveset 2016; Andreacci et al., 2017; Araujo \& Lobo 2020; Rosa et al., 2020). New techniques have used both semi-quantitative and quantitative data (Freitas \& Bolmgren, 2008; Valverde et al., 2016).

We compared the intensities and synchronies of flowering and fruiting using different data collection methods (qualitative, semi-quantitative, and quantitative), and hypothesized that semi-quantitative or quantitative data would provide better evaluations than qualitative data for examining tropical arboreal phenology.

We followed the flowering and fruiting of Himatanthus drasticus (Mart.) Plumel, (Apocynaceae) trees (1.80 - $7.0 \mathrm{~m}$ tall), growing in a gallery forest $\left(12^{\circ} 33^{\prime} \mathrm{S} \times 41^{\circ} 24^{\prime} \mathrm{W} ; 500 \mathrm{~m}\right.$ a.s.l.) in the Chapada Diamantina mountains in northeastern Brazil, a region with dry winters and rainy summers. H. drasticus is endemic to Brazil and occurs in Amazonian, Caatinga, and Cerrado domains (Flora do Brasil, 2020, under construction). 
The phenophases of flower budding, flowering, and immature and mature fruit production were followed from May/2014 to April/2015 in 44 marked individuals. Data collection was based on: (i) quantitative methods - direct counts of flower buds, flowers, and mature and immature fruits; (ii) semi-quantitative methods (Fournier, 1974) which used five class categories $(0-4)$ at $25 \%$ intervals, with the intensities of the phenophases being measured as the ratio of the sum of categories multiplied by 100 and the maximum Fournier number (4) multiplied by the number of individuals (San Martin-Gajardo \& Morellato, 2003); and, (iii) qualitative methods - presence or absence of a phenophase (expressed as the percentage of individuals) (Frankie et al., 1974). Phenophase intensities were measured using analogous approaches. Synchrony analyses were based on qualitative methods: (i) the Augspurger index (1983), obtained by calculating the synchrony of each sampled individual, where the sum of the months in which an individual demonstrated a phenophase is added to the number of months in which the other individuals exhibited that phenophase - with a result equal to 1 indicating perfect synchrony, while a result equal to 0 indicates no synchrony; (ii) the Bencke \& Morellato (2002) index, based on the percentage of individuals in the population manifesting a certain phenological event - which ranges from asynchrony, to low or high synchrony; (iii) circular statistics (Morellato et al., 2010b) performed using Oriana 4.02 software (Kovach 2013). For each phenophase we calculated the length of the mean vector ( $\mathrm{r}$ - the degree of temporal aggregation or synchrony of phenophase activity) - with high $r$ values $(>0.5)$ indicating synchronous phenological activities. The Rayleigh test $(Z)$ determined if the data were distributed uniformly throughout the year $(\mathrm{p}>0.05)$ (Zar, 2010).

Additionally, intraspecific synchrony was analyzed using semi-quantitative and quantitative data according Freitas \& Bolmgren (2008), taking into consideration the overlap between individuals and the degree of flowering and fruiting intensity within that time span. Phenophase intensity was calculated using the numbers of flowers or fruits produced by an individual, divided by the maximum number recorded during the time span considered (one month) (Nassar \& Ramirez, 2004). We calculated the synchronies between the individuals sampled and the overall synchrony of the population. The resulting values ranging from 0 to 1 ; with 1 indicating perfect synchrony and 0 indicating no synchrony.

The resulting graphs are quite different in terms of their flowering and fruiting peaks, with quantitative measures of intensity better expressing resource offerings. In general, the analyses of synchrony of flowering and fruiting in H. drasticus obtained from qualitative, semi-quantitative, and quantitative data indicated asynchrony (Augspurguer, Freitas and Bolmgren indexes and circular analysis) and/or low synchrony for all the phenophases evaluated. The Freitas and Bolmgren index showed the lowest synchrony values based on semi-quantitative and quantitative data. Only circular analysis demonstrated synchrony of immature fruit production, showing a unimodal distribution of this phenophase (Figure 1; Table 1).

Our hypothesis was therefore partially confirmed, as phenophase intensities were best revealed by quantitative and semi-quantitative data and would, for example, favor interpretations of links with resource availability for pollinators and dispersers (Freitas \& Bolmgren, 2008; Souza \& Funch 2015). The qualitative method did not generate easily distinguishable intensity peaks. Data collection using the Fournier method, however, has been widely employed in phenological studies due to its efficiency and standardized measurements (Menezes et al., 2018). Quantitative methods require more intensive field efforts, although they proved to be more accurate in demonstrating the intensities of flowering and fruiting as resources invested in pollination and dispersal processes of $H$. drasticus.

There were no significant differences between the qualitative, quantitative, and semi-quantitative data in terms of identifying phenophase synchrony. The indices used here require large numbers of sampled individuals to sustain adequate and reliable conclusions (Augspurger, 1983; Bencke \& Morellato, 2002; Freitas \& Bolmgren, 2008; Morellato et al., 2010b), as they consider the percentages of individuals in a population that manifest a given phenophase, or employ combinatorial analyses to infer the average possibility of events occurring in the same period, comparing each individual with the others.

We therefore conclude that the methods used to examine phenophase intensities and synchronies yield distinct results that can complement each other, making it important to clearly define the objectives of the project and choose the most appropriate methods of data collection and analysis. We therefore suggest the use of quantitative methods to determine the intensities of flowering and fruiting in studies with tropical trees producing large flowers and fruits that can be easily quantified visually, but qualitative data to examine synchrony, as it requires lower investments in field observations. 


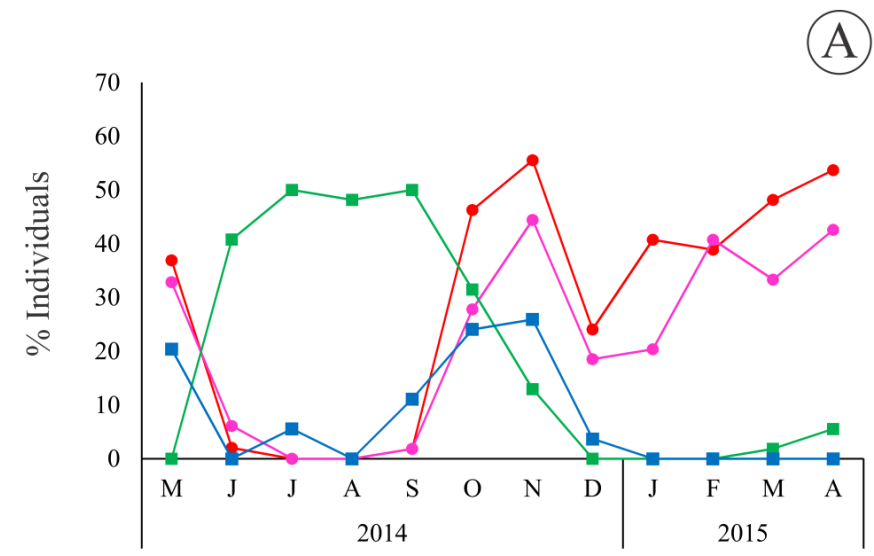

Himatanthus drasticus (Mart.) Plumel

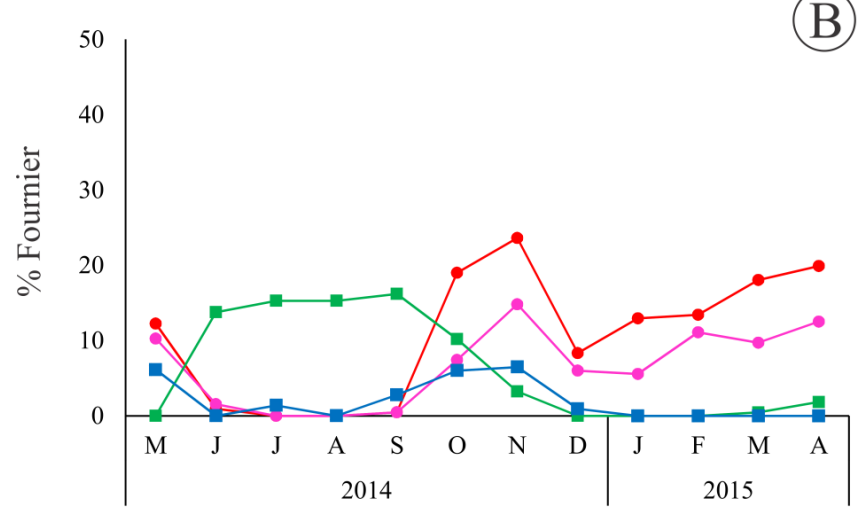

B Flower buds and flowers
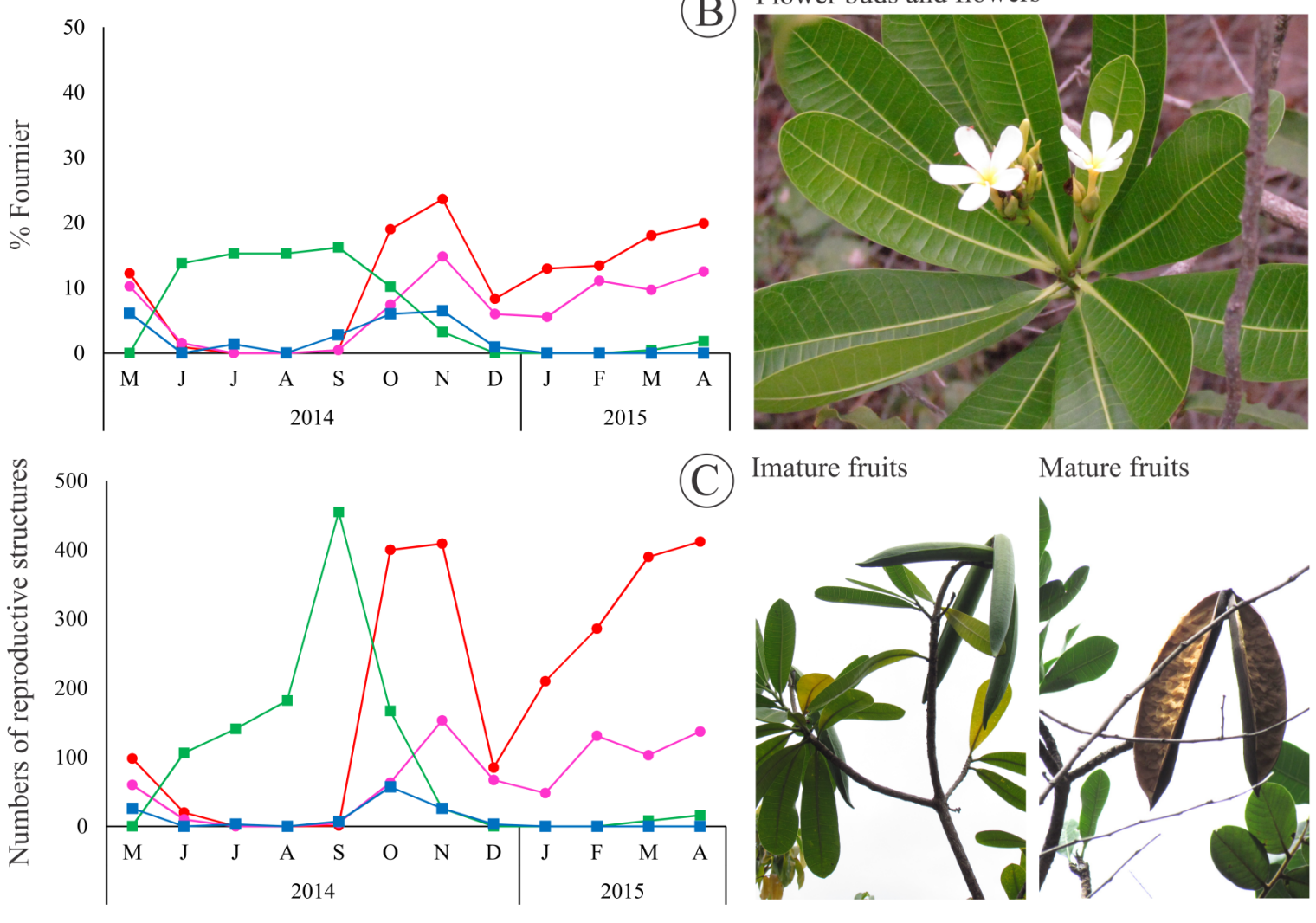

Imature fruits

Mature fruits

$\rightarrow$-Flower buds $\rightarrow$-Flowers $\rightarrow$-Immature fruits $\rightarrow$ - Mature fruits

Figure 1. Flowering and fruiting of Himatanthus drasticus between May/2014 and April/2015 in a gallery forest along the Lençóis River, in the Chapada Diamantina Mountains in northeastern Brazil. (A) Synchrony of individuals; (B) Estimated intensity (Fournier); (C) Quantified intensity. To the right, images showing the species habit, flower buds, flowers, immature fruits and mature fruits. 
Table 1. Synchrony indices for the flowering and fruiting phases of H. drasticus, between May/2014 and April/2015 in a gallery forest along the Lençóis River, in the Chapada Diamantina Mountains in northeastern Brazil.

\begin{tabular}{|c|c|c|c|c|c|}
\hline Analysis & & $\begin{array}{c}\text { Flower } \\
\text { buds }\end{array}$ & Flowers & $\begin{array}{l}\text { Immature } \\
\text { fruits }\end{array}$ & $\begin{array}{c}\text { Mature } \\
\text { fruits }\end{array}$ \\
\hline \multicolumn{6}{|c|}{ Bencke and Morellato } \\
\hline Qualitative & & $1.9-55.6$ & $1.9-51.0$ & $1.9-50.0$ & $3.7-49.0$ \\
\hline \multicolumn{6}{|l|}{ Augspurguer } \\
\hline Qualitative & & 0.37 & 0.32 & 0.32 & 0.21 \\
\hline \multicolumn{6}{|c|}{ Freitas and Bolgrem } \\
\hline semi-quantitative & & 0.11 & 0.01 & 0.1 & 0.02 \\
\hline Quantitative & & 0.06 & 0.01 & 0.08 & 0.02 \\
\hline \multicolumn{6}{|l|}{ Circular } \\
\hline \multirow[t]{3}{*}{ Qualitative } & $r$ & 0.404 & 0.382 & 0.732 & $0.037^{\star}$ \\
\hline & $\mathrm{Z}$ & 28.414 & 21.191 & 67.015 & $0.099^{*}$ \\
\hline & $\mathrm{P}$ & $<1 \mathrm{E}-12$ & $6.26 \mathrm{E}-10$ & $<1 \mathrm{E}-12$ & $0.906^{*}$ \\
\hline
\end{tabular}

Note: ${ }^{*}$ Values that may be less reliable because of low fruiting frequencies (uniform distribution $-\mathrm{p}>0.05$ )

\section{ACKNOWLEDGEMENTS}

The authors thank J. Oliveira, I. Silva, I. Souza and IM. Souza for their help with the fieldwork and discussions concerning the manuscript, the Fundação Chapada Diamantina for providing support in Lençóis, the graduate program in Plant Genetic Resources (Universidade Estadual de Feira de Santana) for infrastructure support.

\section{SUBMISSION STATUS}

Received: 17 Jul. 2020

Accepted: 04 Nov. 2020

Associate editor: Rodrigo Studart Corrêa

\section{CORRESPONDENCE TO \\ Marília Grazielly Mendes dos Santos}

Universidade Estadual de Feira de Santana, Departamento de Ciências Biológicas, Laboratório Flora e Vegetação, Avenida Transnordestina, s/n, CEP 44036-900, Feira de Santana, BA, Brasil

e-mail:mara_cte@hotmail.com

\section{FINANCIAL SUPPORT}

This work was supported by a Masters Degree award by the Fundação de Amparo a Pesquisa do Estado da Bahia (FAPESB 0257/2014).

\section{REFERENCES}

Alexander LW, Woeste KE. Phenology, dichogamy, and floral synchronization in a northern red oak (Quercus rubra L.) seed orchard. Canadian Journal of Forest Research 2016; 46: 629-636.

Alvares CA, Stape JL, Sentelhas PC, Gonçalves JLM de, Saparovek G. Köppen climate classification map for Brazil. Meteorologische Zeitschrift 2013; 22(6):711-728.
Andreacci F, Botosso PC, Galvão F. Fenologia vegetativa e crescimento de Cedrela fissilis na Floresta Atlântica, Paraná, Brasil. Floresta e Ambiente 2017; 24: e20150241.

Araujo MMV, Lobo FAL. Phenology of Copernicia alba in flooded and not flooded environments. Floresta e Ambiente 2020; 27(1): e20170979.

Augspurger C. Phenology, flowering synchrony, and fruit set of six neotropical shrubs. Biotropica 1983; 15: 257-267.

Baldauf C, da Silva AS, Sfair JC, Ferreira R, dos Santos, FAM. Harvesting increases reproductive activity in Himatanthus drasticus (Mart.) Plumel (Apocynaceae), a non-timber forest product of the Brazilian Savanna. Biotropica 2014; 46(3): 341-349.

Bencke CSC, Morellato PC. Estudo comparativo da fenologia de nove espécies arbóreas em três tipos de floresta atlântica no sudeste do Brasil. Revista Brasileira de Botânica 2002; 25 (2): 237-248.

Bolmgren K. The use of synchronization measures in studies of plant reproductive phenology. Oikos 1998; 82:411-415.

Castro-Díez P, Milla-Gutiérrez R, Montserrat-Martí G. Comparison of methods to study plant phenological patterns. The case of Halimium atriplicifolium (Cistaceae) Phyton 2003; 43(1): 59-78.

Flora do Brasil em construção. Himatanthus. [cited 2020 jul. 6] Available from: http://floradobrasil.jbrj.gov.br/reflora/floradobrasil/ FB4621.

Fournier LA. Un método cuantitativo para la medición de características fenológicas em árboles. Turrialba 1974; 24:422-423.

Frankie GW, Baker HG, Opler PA. Comparative phenological studies of trees in tropical lowland wet and dry forest in the lowlands of Costa Rica. Journal of Ecology 1974; 62:881-913.

Freitas L, Bolmgren K. Synchrony is more than overlap: measuring phenological synchronization considering time length and intensity. Revista Brasileira de Botânica 2008; 31: 721-724.

Kovach WL. Oriana for Windows, version 1.03. Pentraeth: Kovach Computer Services; 2013.

Lenza E, Klink A. Comportamento fenológico de espécies lenhosas em um cerrado sentido restrito de Brasília, DF. Revista Brasileira de Botânica 2006; 29(4): 627-638.

Menezes IS, Couto-Santos APL, Funch LS. The influence of El Niño and edge effects on the reproductive phenology and floral visitors of Eschweilera tetrapetala Mori (Lecythidaceae), an endemic species of the Atlantic Forest of northeastern Brazil. Acta Botanica Brasilica 2018; 1(32): 1-11.

Morellato LPC, Alberti LF, Hudson IL. Applications of circular statistics in plant phenology: a case studies approach. In: Keatley M, Hudson IL. (Org.). Phenological Research: Methods for Environmental and Climate Change Analysis. Heidelberg: Springer; 2010b.

Morellato LPC, Camargo MGG, Neves FFDE, Luize BG, Mantovai A, Hudson IL. The influence of sampling method, sample size, and frequency of observations on plant phenological patterns and interpretation in tropical forest trees. In: Keatley M, Hudson IL. (Org.). Phenological Research: Methods for Environmental and Climate Change Analysis. Heidelberg: Springer; 2010a.

Nassar JM, Ramírez N. Reproductive biology of the melon cactus, Melocactus curvispinus (Cactaceae). Plant Systematics and Evolution 2004; 248: 31-44. 
Newstrom LE, Frankie GW, Baker HG. A new classification for plant phenology based on flowering patterns in lowland tropical rain forest trees at La Selva, Costa Rica. Biotropica 1994; 26(2): 141-159.

Pugas RM, Paz JRL da, Neves EL das, Pigozzo CM. Himatanthus bracteatus (A. DC.) Woodson (Apocynaceae): phenology, morphology, and floral biology of a species endemic to the Atlantic Forest. Hoehnea 2018; 45(3): 405-412.

Rodriguez-Perez J, Traveset A. Effects of flowering phenology and synchrony on the reproductive success of a long-flowering shrub. AoB Plants 2016; 8: plw007.

Rosa JC, Mendonça AP, Ribeiro CC, Ribeiro SB. Phenological reproductive pattern of the Attalea speciosa Mart ex Spreng. in pasture area in the central region of Rondônia. Floresta 2020; 50(2): 1335-1344.

San Martin-Garjado I, Morellato LPC. Fenologia de Rubiaceae do sub-bosque em floresta Atlântica no sudeste do Brasil. Revista Brasileira de Botânica 2003; 26(3): 299-309.

Souza IM, Funch LS. Fenologia e modos de polinização e dispersão de Fabaceae em floresta ciliar, Chapada Diamantina, Nordeste do Brasil. Sitientibus serie Ciencias Biologicas 2015; 15: 1-10.

Valverde J, Gómez JM, Perfectti F. The temporal dimension in individual-based plant pollination networks. Oikos 2016; 125:468-479.

Zar JH. Biostatistical analysis. 5 ed. New Jersey: Prentice-Hall; 2010. 